\title{
INVESTIGATIONS ON THE POSSIBILITIES OF REINDEER BREEDING II.
}

\author{
Mikкo VARo \\ Department of Animal Breeding, University of Helsinki
}

Received October 13, 1972

\begin{abstract}
The net increase in the weight of the reindeer calves has been during the first summer 35 and $40 \mathrm{~kg}$ and the second 17 and $25 \mathrm{~kg}$ for the females and males, respectively. There are genetic differences in the development of the weights and measures of the young reindeer. These differences can be utilized in improving the productivity by breeding. Also the change in weight during the winter season seems to be an inheritable feature. The sum of the body length and the chest girth, or the combined measure, looks like being the most useful basis for selection.
\end{abstract}

\section{Introduction}

These results are from experiments initiated in 1962 at Askankangas. The preliminary results have been reported earlier (VARo 1964). Here are reported chiefly the first twoyear weights and measures of the calves born in 1963. The experimental material consists of the calves of a reindeer herd of six bucks and 120 dams. Originally there were 76 calves but in 1965 there were only 64 calves left for various reasons. Thus the material is rather small for any far-reaching conclusions. The group was planned as the first part of a larger experimental program. Since the experimental conditions are extremely severe, an extension of the experiments has so far not come off and we have to present results, the statistical significance of which is not always as good as one could hope for. However, even these results give some indications regarding breeding, the aim of which is the improvement of the productivity of reindeer. The basis for all breeding is the heritability of the economically important quantitative features. In the following this is studied by estimating the heritability coefficients for the progeny of the bucks according to the halfsibcorrelation. Since the level of the weights and measures in different sex groups is quite different, the above correlations have been calculated within the sex groups.

\section{Means and variations of the progeny}

In Tables $1-3$ the studied properties have been presented in the order of their appearance with age. Weighings have been made both in fall and in spring, while measurements have been made only in spring. For practical reasons the weighings and measure- 
Table 1. Means $(\overline{\mathbf{x}})$ and standard deviations (s) of weight and condition. (Grades of condition: $4=$ good, 0 = bad).

\begin{tabular}{|c|c|c|c|c|c|c|c|c|c|}
\hline \multicolumn{2}{|c|}{ Time and property } & $\begin{array}{l}\text { Average } \\
\text { age, days }\end{array}$ & \multicolumn{3}{|c|}{ Females } & \multicolumn{3}{|c|}{ Males } & $\begin{array}{l}\text { Signifi- } \\
\text { cance of } \\
\text { difference } \\
(0-\phi)\end{array}$ \\
\hline Birth weight & & & 38 & 5.720 & 0.502 & 26 & 6.000 & 0.600 & $*$ \\
\hline \multirow[t]{3}{*}{ Fall 1963: } & & 125 & 38 & & & 26 & & & \\
\hline & Weight & & & 40.500 & 4.549 & & 45.462 & 4.438 & $* * *$ \\
\hline & Condition & & & 3.4 & 0.6 & & 3.7 & 0.5 & $*$ \\
\hline \multirow{3}{*}{ Spring 1964:d } & & 344 & 38 & & & 26 & & & \\
\hline & Weight & & & 40.526 & 4.279 & & 46.115 & 4.607 & $* * *$ \\
\hline & Condition & & & 3.1 & 0.7 & & 3.0 & 1.0 & - \\
\hline \multirow[t]{3}{*}{ Fall 1964: } & & 483 & 38 & & & 26 & & & \\
\hline & Weight & & & 57.947 & 5.357 & & 70.346 & 5.946 & $* * *$ \\
\hline & Condition & & & 3.5 & 0.6 & & 3.5 & 0.5 & - \\
\hline \multirow{3}{*}{ Spring 1965: } & & 692 & 38 & & & 26 & & & \\
\hline & Weight & & & 59.000 & 6.431 & & 66.700 & 6.757 & $* * *$ \\
\hline & Condition & & & 3.2 & 0.7 & & 2.7 & 0.6 & $* *$ \\
\hline \multirow[t]{3}{*}{ Fall 1965: } & & 842 & 25 & & & 22 & & & \\
\hline & Weight & & & 59.860 & 4.375 & & 84.041 & 6.915 & $* * *$ \\
\hline & Condition & & & 3.2 & 0.5 & & 3.5 & 0.6 & - \\
\hline \multirow{3}{*}{ Spring 1966: } & & 1052 & 29 & & & 21 & & & \\
\hline & Weight & & & 61.690 & 2.944 & & 81.143 & 7.199 & $* * *$ \\
\hline & Condition & & & 2.8 & 1.1 & & 3.0 & 0.9 & - \\
\hline
\end{tabular}

ments of the whole sample have been carried out simultaneously. This is why there are some variations in the individual ages at the time of the measurements. However, the size of the sample did not allow the levelling out of the variation caused by the differences in ages. Neither is there any reason for a correction as far as the heritability study is concerned, since the average time of birth of the progeny groups from different fathers did not vary. Moreover correction is out of question in practical breeding since the times of birth cannot be foreseen. The variation in times of birth of the calves will increase the error variation and cannot increase the differences between fathers, the presented heritabilities (see later) give therefore the role of genetic factors in the total variation more or less as a cautious estimate. It should be pointed out that the influence of the time of birth (= age) on the results was relatively speaking quite small as is pointed out later. Likewise, the average age of both sexes was very uniform; the males were born, on an average, one day later than the females.

From Table 1 it can be seen that the males are already in the first fall distinctly heavier than the females and the difference in weight seems to be increasing with age. However, 
Table 2. Means $(\overline{\mathbf{x}})$ and standard deviations (s) of measures.

\begin{tabular}{|c|c|c|c|c|c|c|c|c|}
\hline \multirow{2}{*}{ Time and property } & \multirow{2}{*}{$\begin{array}{c}\text { Average } \\
\text { age, days }\end{array}$} & \multicolumn{3}{|c|}{ Females } & \multicolumn{3}{|c|}{ Males } & \multirow{2}{*}{$\begin{array}{c}\text { Signifi- } \\
\text { cance of } \\
\text { difference } \\
(\widehat{0}-\varnothing)\end{array}$} \\
\hline & & $\begin{array}{c}\text { Total } \\
\text { number }\end{array}$ & $\bar{x}$ & $\mathbf{s}$ & $\begin{array}{l}\text { Total } \\
\text { number }\end{array}$ & $\overline{\mathrm{x}}$ & s & \\
\hline Spring 1964: & 344 & 38 & & & 26 & & & \\
\hline Height & & & 81.7 & 3.1 & & 84.6 & 3.9 & $* *$ \\
\hline Length of trunk ${ }^{\mathbf{1}}$ ) & & & 80.4 & 3.0 & & 83.0 & 3.1 & $* *$ \\
\hline Total length ${ }^{2}$ ) & & & 138.2 & 5.2 & & 143.0 & 4.8 & $* * *$ \\
\hline Chest girth & & & 88.0 & 4.6 & & 91.9 & 4.0 & $* * *$ \\
\hline Chest depth & & & 31.5 & 1.4 & & 32.4 & 0.9 & $* *$ \\
\hline Chest width & & & 18.9 & 1.3 & & 19.9 & 1.1 & $* *$ \\
\hline Hip depth ${ }^{3}$ ) & & & 29.9 & 1.9 & & 31.7 & 1.8 & $* * *$ \\
\hline Hip width & & & 20.2 & 1.2 & & 20.8 & 1.3 & - \\
\hline Spring 1965: & 692 & 38 & & & 26 & & & \\
\hline Height & & & 90.3 & 3.3 & & 94.2 & 3.1 & $* * *$ \\
\hline Length of trunk & & & 89.6 & 3.1 & & 92.8 & 4.0 & $* * *$ \\
\hline Total length & & & 154.3 & 6.7 & & 162.7 & 5.5 & $* * *$ \\
\hline Chest girth & & & 98.8 & 4.8 & & 103.2 & 3.8 & $* * *$ \\
\hline Chest depth & & & 36.4 & 2.0 & & 37.8 & 2.9 & $*$ \\
\hline Chest width & & & 21.8 & 1.2 & & 22.4 & 1.2 & $*$ \\
\hline Hip depth & & & 34.1 & 1.9 & & 34.8 & 1.7 & - \\
\hline Hip width & & & 21.8 & 1.3 & & 22.7 & 1.0 & $* *$ \\
\hline
\end{tabular}

1) From the top of Shoulder blade to back.

2) From muzzle to back.

3) In front of hip.

in the third spring the difference in weights is relatively smaller than in the previous fall, which, at least in part, is due to the pregnancy of the females. Somewhat surprising is that the general condition of the females in the spring under consideration was distinctly better than that of the males. The great decrease in the weight and condition of the males that took place during the second winter might be due to the strenuous mating period in the fall.

The increase in weight from birth to the first fall weighing has been $34.8 \mathrm{~kg}$ for females and $39.5 \mathrm{~kg}$ for males. It corresponds to the average increase of $278 \mathrm{~g}$ per day for females and $316 \mathrm{~g}$ per day for males. From the above figures it may also be calculated that the weight increase of the females and the males has been 6.1- and 6.6-fold, respectively, when compared to the weight at birth. Until the following fall weighing - during 358 days - the additional growth has been no more than $17.4 \mathrm{~kg}$ for the females and $24.9 \mathrm{~kg}$ for the males or from half to two thirds of the growth in the first summer. The additional growths correspond to a 3.1- and 4.1-fold birthweight, respectively. The average daily growth for the whole period has been only $49 \mathrm{~g}$ for females and $70 \mathrm{~g}$ for males. But, as can be seen from the spring weights, the weights have not increased at all during the first winter, over a period of more than seven months. During the summer period, into which the growth seems exclusively to concentrate, the daily weight increase must have been 
Table 3. Means $(\overline{\mathbf{x}})$ and standard deviations (s) of some qualitative properties.

\begin{tabular}{|c|c|c|c|c|c|c|c|}
\hline Females & & & & & les & & Significance \\
\hline Time and property & $\begin{array}{c}\text { Total } \\
\text { number }\end{array}$ & $\bar{x}$ & $\mathbf{s}$ & $\begin{array}{c}\text { Total } \\
\text { number }\end{array}$ & $\overline{\mathbf{x}}$ & $\mathbf{s}$ & of difference \\
\hline
\end{tabular}

Spring 1964:

$\begin{array}{lrrrrrrc}\text { Regularity of antlers } & 34 & 3.6 & 0.8 & 25 & 4.0 & 0.0 & - \\ \text { Branchcount of antlers } & 34 & 2.1 & 0.8 & 25 & 2.2 & 1.2 & - \\ \text { Height of antlers } & 34 & 14.9 & 6.1 & 25 & 22.5 & 8.0 & * * * \\ \text { Number of larvae of gadflies } & 38 & 9.3 & 7.8 & 26 & 11.9 & 9.8 & - \\ & & & & & & & \\ \text { ing 1965: } & & & & & & & * \\ \text { Regularity of antlers } & 35 & 3.7 & 0.6 & 26 & 4.0 & 2.0 & * \\ \text { Branchcount of antlers } & 35 & 5.0 & 2.8 & 26 & 6.8 & 2.3 & * * \\ \text { Height of antlers } & 35 & 27.6 & 8.0 & 26 & 35.6 & 8.3 & - \\ \text { Shade } & 38 & 3.2 & 0.5 & 26 & 3.0 & 0.7 & - \\ \text { Quality of hair } & 38 & 2.2 & 0.7 & 26 & 1.9 & 0.8 & - \\ & & & & & & & \end{array}$

Basis for evaluation: Regularity of antlers; regular $=4$, irregular $=0$.

Shade; fair $=1$, dark $=5$.

Quality of hair; good $=1$, bad $=3$.

much greater than the average value. In the period of 140 days between spring and fall weighings the average daily growth was as much as $124 \mathrm{~g}$ for females and $178 \mathrm{~g}$ for males. The rate of growth of the first summer was not reached, however. During the second winter season (the interval between the weighings was again about seven months), there has also been a discontinuity in the weight increase and slight decreases have been observed in the weights of the males. The condition of the animals has been clearly worse in spring than in the fall.

It is evident from Table 2 that the males are also bigger than the females except for the hip width. That the changes in the differences of chest and hip depths, and also possibly of chest width at the age of two, are more insignificant than earlier, may be due to the fact that $78 \%$ of the females have been pregnant.

Table 3 shows that the growth of the antlers of the males is already in the first year distinctly faster than with the females. The figures in the table are means and variations of individuals with antlers. In addition to their bigger size the antlers of the males are also more branched and more regular. In the first year there were four polled females and one polled male. Of these the male and one female grew antlers during the second year and two females during the third year. The lack of antlers in adolescence seems to be at least in part, only due to a delay in the growth of antlers. The number of branches has been given in the table as a sum of the branches in both antlers. In the first year the antlers have been almost exclusively unbranched spikes. In the second year the antlers of the females have mostly had two and those of the males three points.

It can be seen from all the tables that most of the properties of the females have more variation than those of the males. Relatively speaking this is the case also with weights, 
Table 4. Heritabilities $\left(h^{2}\right)$.

\begin{tabular}{|c|c|c|c|}
\hline Time and property & $\mathrm{h}^{2}{ }_{1}$ & $\mathrm{~h}^{2}{ }_{2}$ & $\begin{array}{l}\text { Significance of differ- } \\
\text { ences between fathers }\end{array}$ \\
\hline Birth weight & 0.55 & 0.60 & - \\
\hline \multicolumn{4}{|l|}{ Fall 1963: } \\
\hline Weight & 0.45 & 0.68 & $*$ \\
\hline Condition & 0.00 & 0.00 & - \\
\hline Change in weight winter $1963 / 64$ & 0.96 & 0.96 & $* *$ \\
\hline Change in condition winter $1963 / 64$ & 0.00 & 0.00 & - \\
\hline \multicolumn{4}{|l|}{ Spring 1964: } \\
\hline Weight & 0.04 & 0.06 & - \\
\hline Condition & 0.45 & 0.44 & - \\
\hline Height & 0.00 & 0.00 & - \\
\hline Length of trunk & 0.56 & 0.73 & $*$ \\
\hline Total length & 0.08 & 0.12 & - \\
\hline Chest girth & 0.00 & 0.00 & - \\
\hline Chest depth & 0.00 & 0.00 & - \\
\hline Chest width & 0.00 & 0.00 & - \\
\hline Hip depth & 0.17 & 0.23 & - \\
\hline Hip width & 0.00 & 0.00 & - \\
\hline Regularity of antlers & 0.24 & 0.26 & - \\
\hline Branchcount of antlers & 0.16 & 0.16 & - \\
\hline Height of antlers & 0.08 & 0.12 & - \\
\hline \multicolumn{4}{|l|}{ Fall 1964: } \\
\hline Weight & 0.39 & 1.00 & $* *$ \\
\hline Condition & 0.55 & 0.52 & - \\
\hline Change in weight winter $1964 / 65$ & 0.15 & 0.23 & - \\
\hline Change in condition winter $1964 / 65$ & 0.56 & 0.68 & $*$ \\
\hline \multicolumn{4}{|l|}{ Spring 1965: } \\
\hline Weight & 0.24 & 0.39 & - \\
\hline Condition & 0.00 & 0.00 & - \\
\hline Height & 0.15 & 0.25 & - \\
\hline Length of trunk & 0.15 & 0.21 & - \\
\hline Total length & 0.39 & 0.70 & $*$ \\
\hline Chest girth & 0.34 & 0.49 & - \\
\hline Chest depth & 0.61 & 0.69 & $*$ \\
\hline Chest width & 0.33 & 0.36 & - \\
\hline Hip depth & 0.14 & 0.15 & - \\
\hline Hip width & 0.43 & 0.51 & - \\
\hline Regularity of antlers & 0.27 & 0.30 & - \\
\hline Branchcount of antlers & 0.87 & 1.00 & $* *$ \\
\hline Height of antlers & 0.18 & 0.27 & - \\
\hline Quality of hair & 0.78 & 0.79 & $*$ \\
\hline
\end{tabular}


although the variation in kilograms has generally been lower with females than with males. In the second and third year the variation coefficients have been 8.3 and $9.2 \%$ in the fall weights and 10.0 and $10.9 \%$ in the spring weights, respectively. The wider relative variation in the spring weights suggests that the ability to manage in the winter is an individual characteristic. The results, given later, support this view, since according to them also the genes may have something to do with the changes in weight during the winter season.

\section{Heritability of the characteristics}

As pointed out above, the heritability coefficients have been calculated within the sex groups. Of course it might be useful to study the heritability independently in experimental samples of both sexes since differences are possible. The small size of the sample does not allow, this however, if dependable results are to be obtained. Moreover, in the present stage of reindeer breeding it may be sufficient to have, as a foundation for further plans, the knowledge which shows the average heritability in a sample of both sexes. The heritability coefficients appear in Table 4 . The coefficients $\mathrm{h}^{2}{ }_{1}$ have been calculated so that the total variation includes the variation between the sex groups. On the other hand, when calculating the coefficients $\mathrm{h}^{2}{ }_{2}$ the variation between sexes has been subtracted from the total variation.

The heritability of the weight at birth has been estimated from a somewhat smaller material than in the earlier investigation (VARo 1964). However, the value of the coefficient has remained practically unchanged. The fall weight is one of the few features where the difference between fathers turned out to be significant. The estimates of the heritabilities of the weights in the first and second fall do not differ greatly from each other and the general mean is about $\mathrm{h}^{2}=0.6$.

The heritabilities of the ratings regarding condition are quite contradictory in different years. The big differences can partly be explained, however. Thus it is possible that the differences between fathers as far as the condition of the progeny is concerned remain small in the first fall, since the mothers' care of their calves and other maternal influences determine the condition of the offspring. The high correlations between the size of the mother and the weight development of the calves found in the later investigations (M. VARO and H. VARo 1971) suggest a powerful maternal influence, although the significance of the nursing ability of the mother remains obscure. However, the condition estimated the following spring may be influenced by individual features, and also by the inclinations inherited from the fathers. This is even more true with regard to the condition in the second fall, which can be influenced directly by the individual ability of the animal to seek and utilize fodder. The causes that lower the heritabilities of the spring weights compared to fall weights may have a similar influence on the condition. Thus the condition of the progeny as well as their weights may, after the severe winter $1964-65$, have been due mainly to the unfavourable circumstances. The condition of the progeny in the spring at the age of one has been highly dependent on the father, while at the age of two the influence of the father has no longer been discernible. Possibly the very big differences between the fodder conditions during the winters in question have been one effective factor. Also the earlier mentioned strenuous heat period of the males may prove a contributing factor when the condition in the spring is estimated. 
Table 5. Connection between changes in condition and weight in winter.

\begin{tabular}{ccccccc}
\hline $\begin{array}{c}\text { Change in } \\
\text { condition as } \\
\text { grade points }\end{array}$ & females & $\begin{array}{c}\text { Chinter 1963/64 } \\
\text { males }\end{array}$ & all & females & mantes in weight $(\mathrm{kg})$ & all \\
\hline & & & & & & +13.0 \\
+2 & +5.0 & & +5.0 & +13.0 & & +3.6 \\
+1 & -1.3 & +7.0 & +2.3 & +3.6 & & +1.3 \\
0 & +1.8 & +0.5 & +1.4 & +2.1 & -0.6 & -3.0 \\
-1 & -2.4 & +0.1 & -1.3 & -1.3 & -4.7 & -4.5 \\
-2 & -2.5 & -1.4 & -1.7 & -3.0 & -5.3 & \\
\hline-3 & & -2.0 & -2.0 & & & \\
\hline
\end{tabular}

The significance of the spring weight as an indicator of the hereditary inclination seems to be very much smaller than that of the fall weight. At a higher age the significance seems to be increasing, however. It may by natural that the individual inclinations in the weight increase show up better after a far more favorable summer as far as the fodder is concerned than after a strenuous winter. Since the weights of these age groups will be of crucial importance when planning the breeding, these results suggest that weighings or the compensating measurements have to be made in the fall, preferably before the animals go on heat.

Here it may advisable to discuss in greater detail also the changes of weight and condition during the winter season. It is clear that these properties are interconnected, as far as the estimation of the condition visually and manually is correct. The connection of the measures is visualized by the numerical series given in Table 5 . The fact that the changes in weight follow closely the estimates of condition shows that the estimation has succeeded reasonably well. These heritabilities have also been given in Table 4 . The estimate of the heritability in the changes of weight from the variations between fathers inside the sex groups suggested that in the first winter the genetic factors had a definite influence on the change. The differences between the fathers were very significant $(\mathrm{P}<$ $0.01)$ and the value of the coefficient was $\mathrm{h}^{2}=0.96$. The sex groups showed no differences at the time. In the second winter the sexes were very significantly different from each other, and the heritability of the change in weight had values between 0.15 and 0.23 , depending on whether the calculation had been made as a fraction of the total variation or of the variation within the sex groups. The differences between fathers were not significant in this case. In any case, it is possible, according to the results, that the magnitude of the change in weight during the winter season is dependent also on the inherited properties.

The change in condition during the first winter seemed to be fully independent of genetic factors. This is a logical consequence from the fact that also in the first fall the condition was dependent on other than genetic factors. On the other hand, the change in condition during the second winter had a fairly good value of the heritability coefficient, $\mathrm{h}^{2}=0.56-0.68$, which was due to the significant $(\mathrm{P}<0.05)$ differences between the fathers. The genetic correlation of the changes in weight and condition inside the sex groups was in the first winter $r=0.19$ and in the second winter $r=0.52$. The correlations in phenotypes were $\mathrm{r}=0.42$ and $\mathrm{r}=0.52$, respectively. 
The problem of the changes in weight and condition during the winter season has not been fully investigated as yet. The main reason for the differences in genetic inclinations may be either the differences in ability to deposit nutrients in summertime and reach the corresponding condition in fall or the differences in ability toget fodder in winter. In the former case big changes in weight and condition reflect great adaptability to the variable circumstances in different seasons, while in the latter case the ability to maintain weight and condition as constant as possible, or even to increase them constantly, could indicate an ability to satisfy the need of nourishment also in winter season. These features would be most valuable in reindeer breeding if they could be proved to be genetic in origin. More extensive experiments are, however, necessary to work out this problem satisfactorily. The survival of young reindeer in winter season is in any case one of the fundamental problems in reindeer economy.

A general estimate of the heritabilities of the measures shows that the significance of measures as indicators of genetic inclinations increases with age. This trend is especially clear in the total length and the width of chest and hip. The lower values of the heritabilities of hip depth at older age may again be due to the fact that among females there have been many pregnant individuals. This makes it difficult to obtain comparable measures. It is hard to explain, however, why there are such big differences in the estimates for the length in different years. Here occasional interferences must be accounted for as their influence can be quite substantial in a small sample like this. The heritability of height has stayed fairly low, but this is no doubt mainly due to the fact that it is difficult to measure a half-wild and restless animal often in deep snow.

It is evident that selection resting directly upon weight would offer the best starting point for breeding work aiming at increased weight or body size. In the circumstances prevailing in Lapland, the carrying out of a weighing program on a large scale is extremely difficult in practice, however. This is why the weighings have to be replaced in breeding work extensively with measures which seem to be more reliable and are, simultaneously, easily obtainable. Thus the weight is preferably estimated from the values of body length and chest girth.

Table 4 presents heritability coefficients also for some other properties. The heritabilities of different features in antlers would have been different from those given, had the polled individuals been tabulated here. The animals polled in the first year showed an unusually weak growth of antlers also later. Thus the antlers of the male that was polled in the first year were only $20 \mathrm{~cm}$ high in the second year, while the average size for the other males was $36.2 \mathrm{~cm}$. The figures for the females were 2.5 and $28.1 \mathrm{~cm}$, respectively. Reindeer that had antler buds, however small, in the first year, had antlers of normal size in the second year. A very high heritability degree was obtained for the quality of hair. A buck that has passed on his exceptionally thick, even and shiny hair to all his offspring, has greatly influenced these results.

\section{Correlation coefficients}

The correlations in phenotypes between different features were calculated separately for both sexes. In spite of the small size of the sample, the result was in both cases uniform 
Table 6. Correlations $(\mathrm{r} \times 100)$ in phenotypes of the progeny.

$(\mathrm{P}<0.05, \mathrm{r}>0.25 ; \mathrm{P}<00.1, \mathrm{r}>0.33 ; \mathrm{P}<0.001, \mathrm{r}>0.41)$.

\begin{tabular}{|c|c|c|c|c|c|c|c|c|c|c|c|c|c|c|c|}
\hline & & 1 & 2 & 3 & 4 & 5 & 6 & 7 & 8 & 9 & 10 & 11 & 12 & 13 & 14 \\
\hline 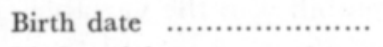 & 1 & & -06 & -47 & -28 & -28 & -22 & -23 & -27 & -18 & -25 & -16 & -27 & -09 & -30 \\
\hline Birth weight $\ldots \ldots \ldots \ldots \ldots \ldots$ & 2 & -06 & & 46 & 25 & 57 & 14 & 40 & 40 & 33 & 42 & 40 & 38 & 19 & 24 \\
\hline Fall 1963: Weight ....... & 3 & -47 & 46 & & 58 & 50 & 23 & 38 & 58 & 42 & 42 & 48 & 44 & 39 & 39 \\
\hline Condition $\quad \ldots \ldots \ldots \ldots \ldots \ldots \ldots \ldots$ & 4 & -28 & 25 & 58 & & 33 & 17 & 24 & 32 & 26 & 25 & 21 & 29 & 17 & 31 \\
\hline Spring 1964 : Weight... & 5 & -28 & 57 & 50 & 33 & & 47 & 41 & 53 & 50 & 68 & 67 & 68 & 54 & 64 \\
\hline Condition $\quad \ldots \ldots \ldots \ldots \ldots \ldots . . . . . . . . .$. & 6 & -22 & 14 & 23 & 17 & 47 & & 42 & 37 & 29 & 55 & 23 & 46 & 30 & 17 \\
\hline Height .............................. & 7 & -23 & 40 & 38 & 24 & 41 & 42 & & 52 & 36 & 45 & 37 & 33 & 18 & 12 \\
\hline Length of trunk ............... & 8 & -27 & 40 & 58 & 32 & 53 & 37 & 52 & & 44 & 59 & 41 & 45 & 33 & 15 \\
\hline Total length ................... & 9 & -18 & 3 & 4 & 26 & 50 & 29 & 36 & 44 & & 44 & 48 & 37 & 52 & 28 \\
\hline Chest girth ..................... & 10 & -26 & 4 & 4 & 25 . & 68 & 55 & 45 & 59 & 44 & & 64 & 60 & 38 & 31 \\
\hline Chest depth .................. & 11 & -16 & 4 & 4 & 21 & 67 & 2 & 37 & 41 & 48 & 64 & & 53 & 43 & 41 \\
\hline Chest width $\ldots \ldots \ldots \ldots \ldots \ldots$ & 12 & -27 & 38 & 4 & 29 & 68 & 4 & 33 & 45 & 37 & 60 & 53 & & 29 & 62 \\
\hline Hip depth ..................... & 13 & -09 & 19 & 3 & 17 & 54 & 30 & 18 & 33 & 52 & 38 & 43 & 29 & & 40 \\
\hline Hip width $\ldots \ldots \ldots \ldots \ldots \ldots . . . . . . . .$. & 14 & -30 & 24 & 3 & 31 & 64 & 1 & 12 & $1:$ & 28 & 31 & 41 & 62 & 40 & \\
\hline Regularity of antlers .......... & 15 & -11 & 2 & 2 & 18 & 07 & 0 & 28 & 17 & 24 & 12 & 16 & 10 & 06 & 03 \\
\hline Branchcount of antlers ....... & 16 & -18 & 25 & 2 & 25 & 13 & 10 & 34 & 18 & 25 & 12 & 13 & 14 & 23 & 11 \\
\hline Height of antlers $\ldots . . . \ldots . . .$. & 17 & -35 & 31 & 48 & 31 & 33 & 34 & 26 & 20 & 20 & 20 & 23 & 31 & 13 & 17 \\
\hline Number of larvae of gadflies & 18 & 25 & 26 & 02 & -03 & 07 & 08 & 20 & 25 & -04 & 19 & 08 & 12 & 03 & -11 \\
\hline Fal1 1964 : Weight ....... & 19 & -23 & 45 & 57 & 35 & 71 & 27 & 36 & 53 & 60 & 41 & 50 & 46 & 54 & 45 \\
\hline Condition $\ldots \ldots \ldots \ldots \ldots \ldots \ldots$ & 20 & 10 & 01 & 17 & 02 & -12 & -10 & -17 & 05 & -07 & -13 & -12 & -11 & 08 & 00 \\
\hline Spring 1965 : Weight... & 21 & -25 & 35 & 41 & 24 & 62 & 23 & 27 & 41 & 61 & 50 & 52 & 46 & 38 & 44 \\
\hline Condition $\ldots \ldots \ldots \ldots \ldots \ldots$ & 22 & -02 & 03 & -02 & -11 & 05 & 05 & -15 & -11 & 11 & 07 & 05 & 06 & 05 & 18 \\
\hline Height ............................. & 23 & -25 & 38 & 48 & 31 & 59 & 33 & 57 & 48 & 60 & 48 & 55 & 37 & 49 & 33 \\
\hline 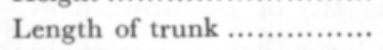 & 24 & -12 & 31 & 43 & 34 & 46 & 32 & 25 & 45 & 46 & 40 & 31 & 30 & 37 & 34 \\
\hline 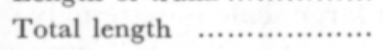 & 25 & -14 & 30 & 38 & 26 & 49 & 27 & 23 & 43 & 47 & 32 & 33 & 31 & 36 & 35 \\
\hline 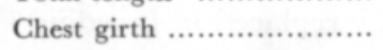 & 26 & -25 & 29 & 44 & 23 & 63 & 21 & 18 & 38 & 53 & 59 & 56 & 49 & 50 & 42 \\
\hline 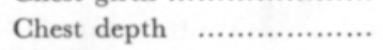 & 27 & -40 & 19 & 43 & 28 & 51 & 20 & 16 & 30 & 32 & 44 & 53 & 33 & 40 & 35 \\
\hline Chest width ..... & 28 & -48 & 27 & 37 & 19 & 55 & 33 & 25 & 33 & 47 & 36 & 46 & 50 & 26 & 46 \\
\hline Hip depth ..... & 29 & -19 & 29 & 38 & 09 & 46 & 27 & 21 & 34 & 47 & 38 & 41 & 25 & 48 & 33 \\
\hline Hip width $\ldots \ldots \ldots \ldots \ldots \ldots \ldots$ & 30 & -42 & 15 & 26 & 22 & 39 & 39 & 11 & 18 & 25 & 33 & 24 & 38 & 19 & 39 \\
\hline Regularity of antlers .......... & 31 & 05 & -07 & 15 & 12 & 11 & 12 & -14 & -06 & -04 & -00 & 23 & 16 & 17 & 18 \\
\hline Branchcount of antlers ....... & 32 & -21 & 13 & 15 & 25 & 25 & 19 & 24 & 08 & 16 & 17 & 21 & 08 & 10 & 09 \\
\hline Height of antlers $\ldots . . . . . . .$. & 33 & 02 & 06 & -02 & 02 & 21 & 28 & 11 & -05 & 05 & 12 & 26 & 03 & 16 & 00 \\
\hline 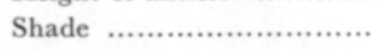 & 34 & -04 & 02 & 06 & 11 & -03 & 22 & 18 & 14 & 13 & 02 & -01 & 00 & 09 & -07 \\
\hline Quality of hair ................. & 35 & 24 & -21 & -38 & -29 & -35 & -09 & -17 & -25 & -30 & -03 & -27 & -30 & -12 & -46 \\
\hline
\end{tabular}

enough to give the weighed means of the coefficients in Table 6. This was done to reduce the numerical information since the differences with a few exceptions were not significant. The first line of the correlation matrix shows that the time of birth seems to have influenced weights and measures, although seldom with any significance. The influence has been definite in the first fall only as regards weight and in the following spring as regards height. In the spring 1965, at the age of two, the time of birth seemed still to have a big influence on the depth and width of chest, and the width of hip. The influence of the time of birth does not deserve very much attention since it seems 


\begin{tabular}{|c|c|c|c|c|c|c|c|c|c|c|c|c|c|c|c|c|c|c|c|c|}
\hline & 16 & 17 & 18 & 19 & 20 & 21 & 22 & 23 & 24 & 25 & 26 & 27 & 28 & 29 & 30 & 31 & 32 & 33 & 34 & \\
\hline 11 & 18 & 35 & 25 & 23 & 10 & 25 & -02 & -25 & -12 & -14 & -25 & -40 & -48 & -19 & -42 & 05 & -21 & 02 & -04 & 24 \\
\hline 20 & 25 & & & & & & & & & & & & & & & & & & 02 & -21 \\
\hline 28 & 29 & 48 & & 57 & & 41 & & & & & & & & & & & 5 & & 6 & -38 \\
\hline 18 & 25 & 31 & & & & 24 & & & & & & & & & & & & & 11 & -29 \\
\hline & 1 & & & 71 & & & & & & & & & & & & & & 1 & -03 & -35 \\
\hline & 1 & 3 & & 27 & & & & & & & & & & & & & & & 22 & -09 \\
\hline 2 & & & & & & & & & & & & & & & & & & & & -17 \\
\hline 1 & & & & & & & & & & & & & & & & & & & 4 & -25 \\
\hline 2 & & & & & & & & & & & & & & & & & & & & -30 \\
\hline 1 & & & & & & & & & & & & & & & & & & & 2 & -03 \\
\hline 1 & & & & & & & & & & & & & & & & & & & & -27 \\
\hline 10 & 1 & 3 & & 46 & & & & 3 & & & & & & & & & & & 0 & -30 \\
\hline 06 & 23 & 1 & 0 & 54 & 08 & 38 & 0 & 49 & 3 & 36 & 50 & & & & & & & 6 & 9 & -12 \\
\hline 0 & 11 & 17 & -11 & 4 & & 4 & & 3 & & & & & & & & & & 0 & -07 & -46 \\
\hline & 28 & 34 & & & & & & & & & & & & & & & & & 0 & -02 \\
\hline 28 & & 55 & -03 & 2 & & & & & & & & & & & & & & & 9 & -18 \\
\hline 54 & 55 & & -11 & 29 & -13 & 2 & 0 & 3 & 2 & 26 & & & & & & & & 2 & -01 & -33 \\
\hline 07 & -03 & -11 & & 05 & 08 & -01 & 0 & 0 & -01 & 09 & 0 & -20 & -12 & -01 & & & & -02 & -24 & 04 \\
\hline 17 & 20 & 29 & 05 & & 24 & 7 & & 6 & & & & & & & & & & & 2 & -38 \\
\hline 00 & -07 & -13 & 08 & 24 & & 07 & 2 & & & & & & & & & & -04 & & & 02 \\
\hline 18 & 20 & 22 & 01 & 76 & 07 & & & 5 & & & & & & & & & & & & -37 \\
\hline $0 s$ & 0 & & & 1 & & 46 & & & & & & & & & & & & & -06 & -17 \\
\hline 28 & 3 & & & & & 58 & 05 & & & & & & & & & & & & & -26 \\
\hline 0 & 16 & & & & & & & 47 & & & & & & & & & & & & -43 \\
\hline 08 & & & & & & & & & & & & & & & & & & & & -34 \\
\hline 16 & & & & & & & & & & 49 & & & & & & & & & -05 & -26 \\
\hline 13 & 20 & & & & & & & & & & & & & & & & & & 6 & -12 \\
\hline ง9 & 20 & & -1 & & & & & & & & & 46 & & & & & & & & -50 \\
\hline 16 & 2 & 2 & -0 & & & & & & & & & & & & & & & & & -24 \\
\hline & 1 & 2 & 02 & & & 5 & & 3 & & 5 & 4 & & & 35 & & & & & 02 & -27 \\
\hline 0 & 1 & 2 & -13 & -01 & & & & & & & & & & & 0 & & 1 & & & -22 \\
\hline 15 & 2 & 4 & $1:$ & 1 & & & & & & & & & & & & 1 & & 42 & -09 & -19 \\
\hline 9o & 3 & 3 & & 2 & -0 & & & & & & & & & & & & 42 & & 12 & -06 \\
\hline 10 & 0 & & -24 & & 0 & & & & & & & & & & & & -09 & 12 & & -24 \\
\hline 02 & -18 & -33 & 04 & -38 & 02 & -37 & -17 & -26 & -43 & -34 & -26 & -12 & -50 & -24 & -27 & -22 & -19 & -06 & -24 & \\
\hline
\end{tabular}

to be mainly due to a few individuals that were born quite late and did not keep pace with the general progress. It appears that the calves born in the last week of May or especially in the beginning of June, in the cirsumstances of Aska, were weaker than the others and remained below average during the whole experimental period. The reason for giving up the correction practice of the weighings and measurements, as mentioned above, was the fact that the apparently big influence of the birth time was really restricted to a few exceptions.

It is not possible or even necessary to discuss the figures in the correlation matrix in 
detail. It should be emphasized, however, that the future progress of a reindeer can be predicted, with good reliability already from the birth weight. Since the correlations between this and later weights are fairly stable and statistically significant, the correlations between weights are also generally speaking adequately high and give pointers to succesful breeding. It can be argued further that the connection between several measures and weights is quite stable, and this possibly allows the replacement of weights with suitable measures when making selections in practice. The cest girth and both measures of length seem to be most suitable for the purpose. The usual body length taken from the withers to the back, which primarily indicates the length of the trunk, is probably more suitable than the total length, since the latter includes the less valuable neck and head.

Since the basis for the selection of reindeer has to be made as simple as possible, chest girth and body length have been combined to a sum variable. The sum of the two measures in question has simply been computed without accent. The correlations of this combined measure and the different weights were as follows:

\begin{tabular}{|c|c|c|c|}
\hline Combined & measure, spring & 1964: & \\
\hline & weight, fall & 1963 & 0.55 \\
\hline & weight, spring & 1964 & 0.66 \\
\hline & weight, fall & 1964 & 0.54 \\
\hline & weight, spring & 1965 & 0.54 \\
\hline Combined & measure, spring & 1965: & \\
\hline & weight, fall & 1963 & 0.51 \\
\hline & weight, spring & 1964 & 0.62 \\
\hline & weight, fall & 1964 & 0.73 \\
\hline & weight, spring & 1965 & 0.85 \\
\hline
\end{tabular}

It can be seen that compared to the coefficient between the weights in the correlation matrix, these correlations prove the combined measure to be a very satisfactory estimate of the weight.

It must be remembered, in the case of the correlations of hair quality, that the lowest mark in the scale has been given for the highest quality. Thus the negative correlations give the connection of the good quality hair with a feature, the value of which increases with the measure. According to this good quality hair seems to indicate generally also good condition and growing ability. It should be mentioned moreover that late born calves seem to have been pestered by gadflies more than the others, which could be one reason for their continuous poor condition.

\section{Other observations}

The influence of the parent on weight. The dependence of the weight of the progeny on the weight and measures of the parent was studied also with an illustrative selection experiment in which the parents were divided into + and - groups according to their weights and combined measures. The progeny were divided after their parents into four groups: $+\mathrm{S}+\mathrm{D},+\mathrm{S}-\mathrm{D},-\mathrm{S}+\mathrm{D}$, and $-\mathrm{S}-\mathrm{D}$. The average differences in weight between the groups $+\mathrm{S}+\mathrm{D}$ and $-\mathrm{S}-\mathrm{D}$ appear in Table 7. In order to eliminate the influence of the sex, the differences in the calves have been computed separately for both sexes and the figures in the table are the means of these values. 
Table 7. Differences in weights of the progeny of plus and minus parents.

\begin{tabular}{lcc}
\hline Time & $\begin{array}{c}\text { Difference (kg) in weights of progeny } \\
\text { as the parents have been graded by } \\
\text { weight }\end{array}$ \\
\hline measures
\end{tabular}

The results suggest that the selection of parents according to the measures or the weights leads at least to an equally favorable change in weights of the offspring. Moreover, the significance of the measurements is emphasized by the fact that the parents have been measured only once, but the weights are the means of four different weighings. Without giving more results it can be added that the selection according to one parent was of course on an average only half as effective as according to both parents. The differences in the spring weights of the calves were influenced much more by the mothers than the fathers, and also here the measures of the mothers proved to be a distinctly better basis for selection than the weights. VostrJakov (1971) has also indicated the big influence of the weight of the mother on the birth weights of the calves as well as on the later weights. These observations suggest, as do the results on the above heritabilities, that the own genetic inclinations of the progeny are of less importance in the development of spring weights than are the fall weights, while the ability of mothers to take care of their calves shows up strongly in the spring. The offspring of good size mothers seem to fare best in the winter.

Somewhat different results were obtained from the investigations where the correlation between the calf and the mother was computed inside the sex groups. Accordingly, the value of the correlation coefficient between the measures of the mothers and the weights of the progeny in the second fall was $\mathrm{r}=0.32^{*}$, while the weights of the mothers gave $\mathrm{r}=0.41^{* *}$. Keeping in mind the big number of the weighings of the mothers and also what has been said above of the spring and fall weights of the offspring, it is evident that the difference between the coefficients is actually quite small, which points to the usefulness of the measures in practice.

Table 8. Dates and weights of birth of the calves by the year and area.

\begin{tabular}{|c|c|c|c|c|c|c|c|c|c|c|c|}
\hline \multirow[t]{2}{*}{ Area } & \multirow[t]{2}{*}{ Year } & \multicolumn{2}{|c|}{ Number } & \multicolumn{4}{|c|}{$\begin{array}{l}\text { Date of birth in May (d) } \\
\text { females }\end{array}$} & \multicolumn{4}{|c|}{$\begin{array}{l}\text { Weight of birth (kg) } \\
\text { females }\end{array}$} \\
\hline & & $\mathbf{f}$ & $\mathrm{m}$ & $\mathrm{x}$ & $\mathbf{s}$ & $\mathbf{x}$ & $\mathbf{s}$ & $\mathrm{x}$ & $\mathbf{s}$ & $\mathbf{x}$ & $\mathbf{s}$ \\
\hline Aska & 1963 & 42 & 30 & 13.9 & 0.9 & 14.7 & 1.1 & 5.694 & 0.078 & 6.027 & 0.123 \\
\hline Aska & 1964 & 35 & 37 & 12.2 & 0.8 & 13.0 & 0.6 & 4.609 & 0.112 & 5.191 & 0.159 \\
\hline Kielajoki & 1964 & 28 & 23 & 22.7 & 0.8 & 20.9 & 1.1 & 4.446 & 0.169 & 4.878 & 0.162 \\
\hline Aska & 1965 & 16 & 10 & 15.6 & 1.7 & 14.6 & 2.0 & 4.713 & 0.207 & 5.100 & 0.245 \\
\hline
\end{tabular}




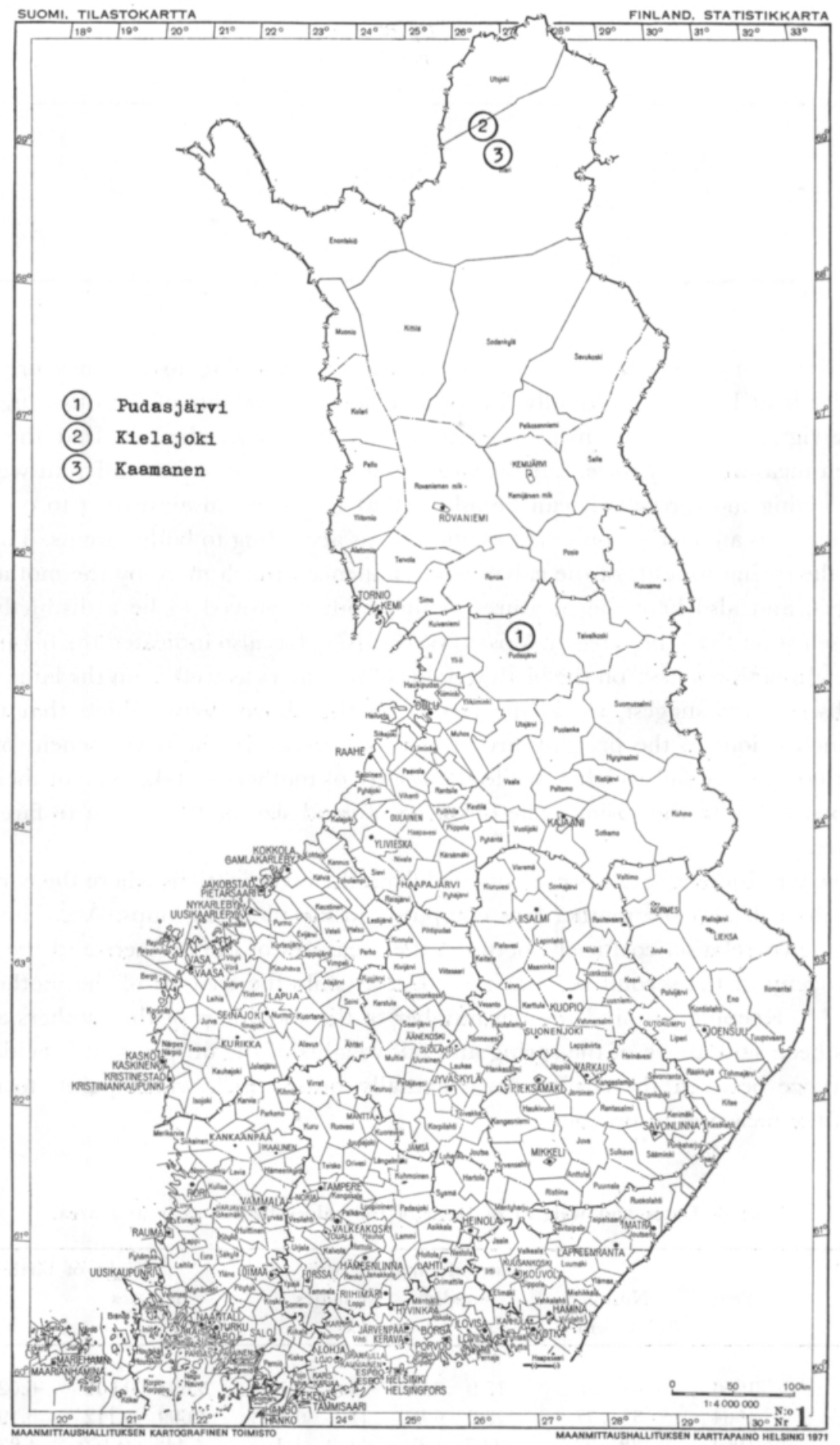

Figure 1. Experimental sites in northern Finland (Pudasjärvi = Aska). 
In addition to the results from the experimental area of Aska at Pudasjärvi, information has also been obtained about the times and birth weights of calves from the experimental group of Kielajoki at Inari (see enclosed map, Figure 1) in 1964 and 1965. This group dispersed later, but the results are seen in Table 8 . They show that the male calves have always been heavier than the females. It is also evident that birth weights may have a very big yearly variation. This is evident especially in the results of Aska in 1963 and 1964. The calves came both years from the same herd, even if not exclusively from the same parents. Thus they are mainly either half or full sisters. In spite of this, the calves of both sexes were very significantly heavier in 1963 than in 1964. The differences were $1.085 \mathrm{~kg}$ for females and $0.836 \mathrm{~kg}$ for males. The former year was quite good for grazing while the latter was very poor. The calves born in Aska in 1965 are offspring of the dams born in 1963. The lower weights of these calves may be mainly due to the young age of the mothers.

The calves born in Kielajoki are distinctly, although not significantly lighter than those born in Aska. On an average in 1963, the parents in Kielajoki and in Aska were of the same age.

Times of birth in Aska have been practically the same every year. The calves of 1964 were born 9 days later in Kielajoki than in Aska, on the average. The difference is very significant. It should be mentioned that the experimental animals were moved later to Kaamanen.

The order of superiority of the bucks. The question of the breeding efficiency became quite interesting when the bucks were arranged according to the means of their 1963 progeny separately for both sexes. They were graded from 1 to 6 for altogether 25 properties including all weights, measures and estimates of condition. Grade 6 indicates the most favorable property. When the correlation within groups was computed from these ratings it was $0.49^{* * *}$ and $0.46^{* * *}$ according to female and male offspring, respectively. These coefficients show that the list of superiority of the bucks is fairly uniform according to all the above values. This may be explained as a reflection of size, the heritability of which apparently is very high, both in measures and in weights. Moreover, size plays a considerable role in the maintenance of individual condition. Differences of this type between the bucks are of considerable practical significance. In fact the selection of qucks is of crucial importance in the reindeer breeding initiated so far (VARO 1971).

\section{REFERENCES}

VARo, R. M. 1964. Tutkimuksia poron jalostusmahdollisuuksista. Summary: Investigations on the possibilities of reindeer breeding. Ann. Agric. Fenn. 3: 296-310.

VARo, R. M. 1969. Långsiktiga renavelsfrågor. Samnordisk renforskningskonferens Gällivare 1969. Kungl. Lantbruksstyrelsen, Medd. B 88: 31-40 1971.

VAro, R. M. 1971. Poronjalostuksen käytännöllinen toteuttaminen. Poromies 3: 9-11.

VARo, R. M. \& VARO, H. 1971. The milk production of reindeer cows and the share of milk in the growth of reindeer calves. Maatal.tiet. Aikak. 43: 1-10.

Votsrjakov, P. N. 1971. Poronhoito ja jalostustyö Neuvostoliitossa. Esitelmä Porosymposiumissa Rovaniemellä 26.-27. 5. 1971. Poromies 5: 4-11. 


\title{
SELOSTUS
}

\section{TUTKIMUKSIA PORON JALOSTUSMAHDOLLISUUKSISTA II.}

\author{
MikKo VARo \\ Kotieläinten jalostustieteen laitos, Helsingin yliopisto, Viikki
}

Tässä tutkimuksessa esitettävät tulokset on saatu pääasiassa samasta eläinaineistosta, josta saadut ensimmäiset koetulokset on julkaistu samannimisessä suomenkielisessä julkaisussa (VARO 1964).

Painon ja kunnon kehitys kolmen ensimmäisen elinvuoden aikana osoittaa (taulukko 1), että kasvu on talvikauden ajan lähes pysähdyksissä; uroksilla havaitaan painojen jopa laskeneen. Urokset ovat kuitenkin sekä painoltaan että useimmilta mitoiltaan (taulukko 2) naaraita selvästi kookkaampia.

Painojen periytymisasteet (taulukko 4) ovat tyydyttävän suuret, joskin pienestä aineistosta johtuen epävarmat. Painon muutos talvella - joko lisääntyminen tai väheneminen -, näyttää olevan perinnöllisiin taipumuksiin perustuva piirre. Kevätpainot ovat kasvutaipumuksen osoittajina syyspainoja epävarmempia ilmeisesti juuri siksi, että eri yksilöiden kyky selviytyä talvesta on erilainen. Kunnon huononeminen eräillä yksilöillä ilmenee myös painon laskuna (taulukko 5).

Eri ominaisuuksien väliset yhteydet on esitetty taulukossa 6 korrelaatiokertoimin. Merkityksellisimpiä ovat eri painojen samoin kuin myös mittojen väliset korrelaatiokertoimet, jotka osoittavat alkukehityksessään hyvin edistyneiden yksilöiden yleensä säilyttävän asemansa myös myöhemmin. Muutamat hyvin myöhään syntyneet yksilöt jäävät yleensä pysyvästi jälkeen normaaliaikaan syntyneistä. Painavilla, hyvin kasvaneilla yksilöillä on yleensä muita parempi karvan laatu. Vanhempien valinnalla voidaan jälkeläisten painonkehitystä parantaa (taulukko 7). Käytännön jalostustyössä näyttää ns. yhteismitta, eli rinnanympäryksen ja pituuden summa, sopivimmalta mitalta suoritettaessa valintaa kasvunopeuden parantamiseksi. 